\title{
GMR
}

\section{Identification and mapping of resistance genes to Phakopsora pachyrhizi in soybean (Glycine max L.) accession PI 594767-A}

G.A.F. Rocha, D.P. Alves, J.C. Oliveira and S.H. Brommonschenkel

Programa de Pós-Graduação em Genética e Melhoramento, Laboratório de Genômica, Universidade Federal de Viçosa, Viçosa, MG, Brasil

Corresponding author: G.A.F. Rocha

E-mail: gafrocha@usp.br

Genet. Mol. Res. 15 (3): gmr.15038475

Received January 21, 2016

Accepted March 11, 2016

Published August 5, 2016

DOI http://dx.doi.org/10.4238/gmr.15038475

Copyright $(2016$ The Authors. This is an open-access article distributed under the terms of the Creative Commons Attribution ShareAlike (CC BY-SA) 4.0 License.

ABSTRACT. The goal of this study was to study resistance inheritance in the soybean (Glycine max L.) accession PI 594767A to the Phakopsora pachyrhizi isolate PPUFV02, and map the resistance gene(s) identified using microsatellite markers. Crosses between PI 594767-A and the susceptible cultivar 'Conquista' gave rise to the segregating subpopulations $26 \mathrm{C}-2$ and $26 \mathrm{C}-5$, which in the $\mathrm{F}_{2}$ generation were evaluated for their reactions to PPUFV02. In addition, analyses with microsatellite markers linked to the Rpp1-Rpp5 loci were also performed. The segregation pattern obtained in $26 \mathrm{C}$ 2 revealed that resistance was governed by a recessive gene; a 1:2:1 segregation pattern was observed in $26 \mathrm{C}-5$, indicating control by a gene with partial dominance. This variability may have been caused because environmental conditions, particularly temperature, when 26C-5 was assessed were unfavorable for pathogen development, allowing the phenotypic expression of heterozygous alleles in PI 594767-A. A 
resistance gene was located in the soybean linkage group $\mathrm{G}$, in the genomic region between Sct_187r2 and Sat_064 that contains the Rpp1 locus. Resistance in PI 594767-A is probably conferred by a new Rpp 1 gene allele, because this accession has a haplotype for Sct_187r2 and Sat 064, which differs from haplotypes of accessions that also contain resistance alleles that map the Rpp1 locus. The use of Sct_187r2 and Sat 064 will facilitate the introgression of the resistance allele from PI $594767-A$ and its pyramiding with other resistance genes into genotypes with superior agronomic characteristics, in order to obtain cultivars with broad-spectrum resistance to $P$. pachyrhizi.

Key words: Asian rust; Disease resistance; Genetic analysis; Genetic inheritance; Resistance genetic mapping

\section{INTRODUCTION}

Asian soybean rust (ASR) caused by the fungus Phakopsora pachyrhizi Sydow \& Sydow is the main soybean (Glycine max L.) disease. It was first described in Japan in 1902, and quickly spread to soybean-producing countries worldwide. In Brazil, ASR was first reported in 2001 in the State of Rio Grande do Sul (Yorinori and Lazzarotto, 2004). Due to the rapid dispersal of its spores by wind and increased human mobility, ASR is currently found in all soybean-producing areas in Brazil (Freire et al., 2008; Goellner et al., 2010).

The damage caused by ASR is variable, because disease severity varies with the season and region affected. Poor weather conditions may result in a $10-90 \%$ reduction in soybean yield (Hartman et al., 1999). The disease is characterized by tiny brown dots that develop into pustules on the top of the leaves. These lesions may coalesce in severe infections, causing yellowing and premature leaf drop. Symptoms can appear on all aerial parts of the plant, but mainly occur on the leaves. Rust not only reduces the yield but also adversely affects the filling and quality of the grains by reducing their weight, generating empty pods and green seeds, and reducing the quality of various products derived from soybeans.

Resistance of soybean genotypes to ASR can be mainly distinguished by the lesion type. Susceptible reactions are characterized by light brown lesions ("TAN" lesion type), and resistance reactions are characterized by reddish-brown lesions ("RB" lesion type). In general, "TAN" lesions have two to five uredias at lesion, whereas "RB" lesions have zero to two. There is also an immunity with flecks reaction ("IF"), in which no macroscopic symptoms of the disease are observed (Goellner et al., 2010).

The process of infection by $P$. pachyrhizi involves the deposition of a uredospore on the host surface, germination, and appressorium formation. Penetration into the plant tissue occurs directly through the cuticle, followed by intercellular growth and haustorium formation. Under favorable environmental conditions, such as a temperature of between $15^{\circ}$ and $29^{\circ} \mathrm{C}$ and high relative humidity four to five days after inoculation, it is possible to observe the symptoms. Six to eight days after inoculation, uredias appear on the abaxial surface of leaves, which release uredospores (Marchetti et al., 1976; Melching et al., 1989).

Several control methods are used in order to mitigate damage to soybean production caused by ASR. Disease control mainly involves the application of triazole and strobilurin fungicides, separately or mixed. However, the use of fungicides increases the total production

Genetics and Molecular Research 15 (3): gmr.15038475 
cost by about 3.5\% per application, which reduces the economic return of the culture. Strategies to combat ASR include the following: i) chemical control, ii) adoption of fallowing, iii) use of early maturing cultivars, iv) planting early in the sowing season, v) adjusting planting density, and vi) use of resistant cultivars (Yorinori and Lazzarotto, 2004; Souza et al., 2014).

The use of resistant varieties is the ideal measure for ASR control, because it has lower production costs and less environmental impact than fungicide applications (Souza et al., 2014; Rodrigues et al., 2015). In Brazil, the resistant varieties TMG 801 and TMG 803 that exhibit the "RB" lesion type were available for commercial planting in the 2009/2010 harvest. These varieties were called "Inox", in allusion to the fact that they exhibit resistance to rust, and when infected they exhibit little disease progression and low sporulation rates (Fundação MT, http://www.fundacaomt.com.br/). In addition, in the 2010/2011 harvest, Embrapa launched another resistant variety called BRSGO 7560. These varieties have partial resistance to soybean rust, and when infected they exhibit little disease progression and low sporulation rates (Embrapa, http://www.cpac.embrapa.br/noticias/noticia_completa/201/). However, the resistance of these cultivars in the field can be overcome, because the pathogen has considerable genetic variability.

Due to the difficulties inherent in obtaining varieties with effective monogenic resistance, the pyramiding of gene main effects and selecting genotypes with partial tolerance or resistance to disease are the main strategies for ASR management. The use of tolerant or partially resistant varieties does not preclude disease occurrence, but has the advantage of being effective against several strains of this fungus, and reduces the number of fungicide applications required for disease control (Oliveira et al., 2005; Yamanaka et al., 2010).

Six gene loci that confer resistance to ASR have been identified (Rpp1, Rpp2, Rpp3, Rpp4, Rpp5, and Rpp6) (Bromfield and Hartwig, 1980; McLean and Byth, 1980; Hartwig and Bromfield, 1983; Hartwig, 1986; Garcia et al., 2008; Li et al., 2012). Costa (2010) assessed 33 soybean genotypes for resistance to a monopustular isolate of P. pachyrhizi (PPUFV02), eight of which had these resistance genes. PPUFV02 was avirulent in five genotypes containing the resistance genes Rpp2, Rpp4, and Rpp5. Moreover, some accessions that had not been characterized, such as PI 594767-A, exhibited resistance to this isolate.

Yamanaka et al. (2011) assessed the resistance of 66 soybean genotypes to a highly virulent Brazilian isolate called BRP-2, and found that PI 594767-A was the only genotype that did not have any uredias or uredospores up to two weeks after inoculation. However, the genetic control of resistance in this accession is unknown, so characterizing the gene(s) that confer resistance in PI 594767-A will contribute to the adoption of new strategies for the development of durable resistance to ASR.

This study investigated the resistance inheritance pattern of PI 594767-A to the monopustular P. pachyrhizi isolate PPUFV02, and relationships between the gene(s) identified and the genes already described using genetic mapping with microsatellite markers.

\section{MATERIAL AND METHODS}

\section{Genetic material}

The resistant accession PI 594767-A and a susceptible cultivar 'Conquista' were crossed, producing six $\mathrm{F}_{1}$ seeds. The $\mathrm{F}_{1}$ seeds (26C-1 to $26 \mathrm{C}-6$ ) were planted in a greenhouse in $3-\mathrm{dm}^{3}$ pots containing a mixture of soil, Plantmax ${ }^{\circledR}$ substrate, and manure at a ratio of 3:1:1.

Genetics and Molecular Research 15 (3): gmr.15038475 
The pots were watered daily by sprinkler and fertilized according to the recommendation for the culture (Ribeiro et al., 1999). To confirm that the plants from this cross were hybrids, a polymorphic microsatellite locus analysis was conducted between the parents. After verifying their hybrid status, two $\mathrm{F}_{1}$ plants were randomly selected to produce the segregating subpopulations 26C-2 and 26C-5. $\mathrm{F}_{2}$ seeds derived from $\mathrm{F}_{1} 26 \mathrm{C}-2$ and $26 \mathrm{C}-5$ plants were planted to produce two segregate subpopulations. The subpopulation derived from a selfing $26 \mathrm{C}-2$ plant consisted of 250 plants, and the subpopulation derived from a selfing $26 \mathrm{C}-5$ plant contained 364 plants.

\section{Inoculation}

Plants were inoculated at the developmental stage V2-V3, as described by Fehr and Caviness (1977). Plants used as controls and the subpopulation 26C-2 were inoculated on July 14, 2011. The subpopulation 26C-5 and corresponding controls were inoculated on February 15, 2012. For inoculation, PPUFV02 spores were obtained from plants of the 'Conquista' cultivar and stored at $-80^{\circ} \mathrm{C}$. The uredospores were subjected to heat shock for $10 \mathrm{~min}$ at $40^{\circ} \mathrm{C}$ in a water bath, and rehydrated for $24 \mathrm{~h}$ to break their dormancy (Furtado et al., 2008). The concentration of uredospores was then determined by counting them in a Neubauer chamber using an optical microscope (Olympus CX40, Olympus Latin America, USA). Inoculations were made with a direct air atomizer using a suspension of $1.0 \times 10^{5}$ uredospore $/ \mathrm{mL}$ in distilled water + Tween $20(0.01 \%)$. After inoculation, the plants were kept in a mist chamber at $25^{\circ} \mathrm{C}$ in the dark for $24 \mathrm{~h}$. They were then transferred to a greenhouse, where they remained until the pods were harvested. As a control, 15 'Conquista' plants (susceptible standard) and 15 PI 594767-A plants (resistance pattern) were used in the inoculations.

\section{Evaluation}

A resistance assessment of the two subpopulations was performed at 8,10 , and 12 days post-inoculation by classifying the plants by their symptoms ("RB", "TAN", or "IF"). Data obtained from the phenotypic analysis were subjected to a chi-square adherence test ( $\mathrm{P}$ $<0.05)$, which tested the segregation hypothesis of a single recessive gene (3:1) or partial dominance $(1: 2: 1)$.

\section{Genetic mapping}

DNA was extracted according to the protocol described by Doyle and Doyle (1987), with modifications. The concentration, quality, and integrity of the extracted DNA were evaluated by electrophoresis on a $1 \%$ agarose gel, followed by staining with ethidium bromide and visualization under an ultraviolet light photodocumenter. Known quantities of phage lambda DNA in the gel were applied at concentrations of 50 and $100 \mathrm{ng}$. Subsequently, DNA dilutions were made to a concentration of $5 \mathrm{ng} / \mu \mathrm{L}$.

For the segregation analysis of the microsatellite loci, primers that amplify the microsatellite loci were used to link to five of the known loci of resistance to P. pachyrhizi (Rpp1, Rpp2, Rpp3, Rpp4, and Rpp5). The oligonucleotides used in this study were purchased from Sigma-Aldrich Brazil and are listed in Table 1.

Genetics and Molecular Research 15 (3): gmr.15038475 
Table 1. Oligonucleotides used for the amplification of microsatellite loci connected to resistance genes to Asian soybean rust.

\begin{tabular}{|c|c|c|c|}
\hline SSR marker and Rpp locus & $\begin{array}{l}\text { Linkage } \\
\text { group }\end{array}$ & Primer sequence 1 & Primer sequence 2 \\
\hline Sat_164 & $\mathrm{G}$ & GTGATCTTCGAAAGTTCAAT & GCTGTCCCTGAACAAGACTAT \\
\hline \multicolumn{4}{|l|}{ BARCSOYSSR_18_1865 } \\
\hline \multicolumn{4}{|l|}{ BARCSOYSSR_18_1875 } \\
\hline Sat_191N & $\mathrm{G}$ & GCATGACTTGGGTTTCACGTATAG & CGCGATCATGTCTCTGCCATCAGC \\
\hline Satt191 & $\mathrm{G}$ & CGCGATCATGTCTCTG & GGGAGTTGGTGTTTTCTTGTG \\
\hline Rpp1 & G & & \\
\hline Sct_187r1 & G & ATAGTTTCACATTAGGGTGTGGGG & GAGTGGGTCATTTGAGTACGACTTTTC \\
\hline Sct_187r2 & G & ACTCCTCTGTAGTGTGGCTTCTTTGCC & CATGATGACCAACAATGGCTTTCAATC \\
\hline Sct_187r3 & G & CGTGTATTTGGGATAGCTGTGAAAT & GTGTGAAGATTGCCTTACCAACCTA \\
\hline Sct_187 & G & CATGCTCCCATTCTCT & AACATTGGCTTTTTACTTAG \\
\hline Sat_372 & $\mathrm{G}$ & GCGTCTCGAGGTAATTATCTATTTATCTTTT & GCGAGTTTGGTAACATCGAGTATTGAT \\
\hline Sat_372-1N & G & GATTCACGAACTGTATTTCCTC & GACAGAGTCGCAATATACTCATC \\
\hline Sat_064N & G & CGGCCTTACTTATCCATTTGCCATCC & CCTAAGACTACTCGGTTTTACACTGCAC \\
\hline Sat_064 & $\mathrm{G}$ & TAGCTTTATAATGAGTGTGATAGAT & GTATGCAAGGGATTAATTAAG \\
\hline Sat_165 & $\mathrm{J}$ & GCGGACAGGCAGCCACACATCTTA & GCGGATTAAATCAGTTTGTATCGA \\
\hline Satt622 & $\mathrm{J}$ & GCGGTGTAGGTAATAATTTTAATTCTCAT & GCGGTGTAGGTTTCACACTTCATTCAC \\
\hline Sat_255 & $\mathrm{J}$ & GCGGCATGTCATGGTATACGTAACTTTAGA & GCGCAACTGAAGCAAGAAAAGAAACCT \\
\hline Rpp2 & $\mathrm{J}$ & & \\
\hline Satt620 & $\mathrm{J}$ & GCGGGACCGATTAAATCAATGAAGTCA & GCGCATTTAATAAGGTTTACAAATTAGT \\
\hline Satt708 & $\mathrm{C} 2$ & GCGCAATTTTAAGAGATTTTCGGGATAA & GCGACTCGGTTGATTTTTTTTTCAATTTTTT \\
\hline Satt460 & $\mathrm{C} 2$ & GCGCGATGGGCTGTTGGTTTTTAT & GCGCATACGATTTGGCATTTTTCTATTG \\
\hline Satt079 & $\mathrm{C} 2$ & AGTCGAAGATACACAATTAGAT & CTTTTAGACACAAATTTATCACT \\
\hline Rpp3 & $\mathrm{C} 2$ & & \\
\hline Satt307 & $\mathrm{C} 2$ & GCGCTGGCCTTTAGAAC & GCGTTGTAGGAAATTTGAGTAGTAAG \\
\hline Sat_164 & $\mathrm{G}$ & GTGATCTTCGAAAGTTCAAT & GCTGTCCCTGAACAAGACTAT \\
\hline Satt288 & G & GCGGGGTGATTTAGTGTTTGACACCT & GCGCTTATAATTAAGAGCAAAAGAAG \\
\hline Rpp4 & G & & \\
\hline Satt612 & G & GTCATACTGGGTGTTTCATTTATGAC & GCGCCTTTTAGTCTCTGAAAGTATTT \\
\hline Sat_166 & $\mathrm{N}$ & GCGCTAATTTATCGGGACCCAACATAT & GCGGAAATAGTGCATTGATGAAAAACA \\
\hline Rpp5 & $\mathrm{N}$ & & \\
\hline Sat_275 & $\mathrm{N}$ & GCGCGCTGGCAATTATTCAAAACTTAACGAT & GCGAAGGCTACGGTGAATAGAAAGGAC \\
\hline Sat_280 & $\mathrm{N}$ & GGCGGTGGATATGAAACTTCAATAACTACAA & $\begin{array}{l}\text { GGCGGGCTTCAAATAATTACTATAAAACT } \\
\text { ACGG }\end{array}$ \\
\hline sc21_3360M & $\mathrm{G}$ & AGGATAAGTTAGGTGGTATG & AGTTTTAGAGAACGGTGAGG \\
\hline sc21_3420M & G & ATAATAATGAGTGCTGCCTG & ACAATCCGCACAACTACAAC \\
\hline sc21_4058M & G & CTAAAAGTCTGCAACTTAGC & ACGATTTGGCAGTATATGAC \\
\hline sc21_4808M & $\mathrm{G}$ & TGAGTTCAATTTGTCTCCTC & ACTGACCACCAAATACAAAG \\
\hline
\end{tabular}

Sequences available at http://www.soybase.org/.

Polymerase chain reactions (PCRs) were performed in an Applied Biosystems ${ }^{\circledR}$ GeneAmp ${ }^{\circledR}$ PCR System 9700 under the following conditions: $94^{\circ} \mathrm{C}$ for 5 min followed by 40 cycles at $94^{\circ} \mathrm{C}$ for $40 \mathrm{~s}, 55^{\circ} \mathrm{C}$ for $40 \mathrm{~s}, 72^{\circ} \mathrm{C}$ for $40 \mathrm{~s}$, and a final step of $25 \mathrm{~min}$ at $72^{\circ} \mathrm{C}$. The PCRs contained PCR buffer (10 mM Tris- $\mathrm{HCl}, \mathrm{pH} 8.3$, and $50 \mathrm{mM} \mathrm{KCl}), 1.5 \mathrm{mM} \mathrm{MgCl}, 0.2$ $\mathrm{mM}$ dNTP mix, $0.4 \mu \mathrm{M}$ oligonucleotide, $1 \mathrm{U}$ Taq DNA polymerase, and $30 \mathrm{ng}$ DNA in a final volume of $20 \mu \mathrm{L}$.

All of the oligonucleotides were tested with both parents to verify the existence of polymorphisms in the amplified loci. After selection of the polymorphic loci, a modified grouped segregant analysis strategy (bulked segregant analysis) (Michelmore et al., 1991) was used to identify markers that were associated with ASR resistance genes. In this study, DNA samples from similar individuals were not grouped. Ten individuals with the resistant phenotype and 10 susceptible individuals were analyzed using markers that exhibited polymorphism in the parents (open Bulk).

The primers that amplified polymorphic loci linked to the resistance genes were

Genetics and Molecular Research 15 (3): gmr.15038475 
used in a genotype analysis of the two segregating subpopulations, which totaled 614 plants. Firstly, an aliquot of the PCR products was analyzed on a 1\% agarose gel to verify the presence of amplicons, the size of which was estimated by comparisons with markers of known molecular weight. Amplicon visualization was performed using an ultraviolet light photodocumenter. After amplification, the amplicons were analyzed using an ABI PRISM ${ }^{\circledR}$ 3100 Genetic Analyzer (Applied Biosystems) that collected data in a virtual filter D using the Data Collection software (Applied Biosystems). Amplicon size (bp) was estimated using GeneMapper $^{\circledR}$ version 3.5 (Applied Biosystems).

The data obtained from the microsatellite marker loci were placed in two matrices, the rows of which were coded with the different microsatellite loci and the resistance locus and the columns with information on the 250 and 364 individuals in each subpopulation. These data were used for linkage analysis and map construction in GQMOL 6.1 (Cruz and Schuster, 2006) using the Kosambi mapping function (Kosambi, 1944). The binding test was a LOD [logarithm (base 10) of odds] score greater than 3.00, and the maximum percentage of recombination was $30 \%$.

\section{RESULTS}

Under favorable temperature and relative humidity conditions for the development of P. pachyrhizi, the experiment with subpopulation 26C-2 showed that PI 594767-A plants used as controls exhibited a resistance reaction to P. pachyrhizi that was characterized as the "RB" lesion type without sporulation on either leaf surface. 'Conquista' plants exhibited the "TAN" lesion type with abundant sporulation, particularly on the abaxial surface of the leaves, confirming the susceptibility of this cultivar to the isolate used (Figure 1).

The segregating subpopulation $26 \mathrm{C}-2(\mathrm{~N}=250$ plants) contained 60 resistance plants with "RB" lesions that were similar to those observed in PI 594767-A, and 190 susceptible plants with "TAN" lesions that were similar to those observed on the "Conquista' plants. This ratio (3:1) indicated that resistance in PI 594767-A is controlled by a recessive gene (Table 2).

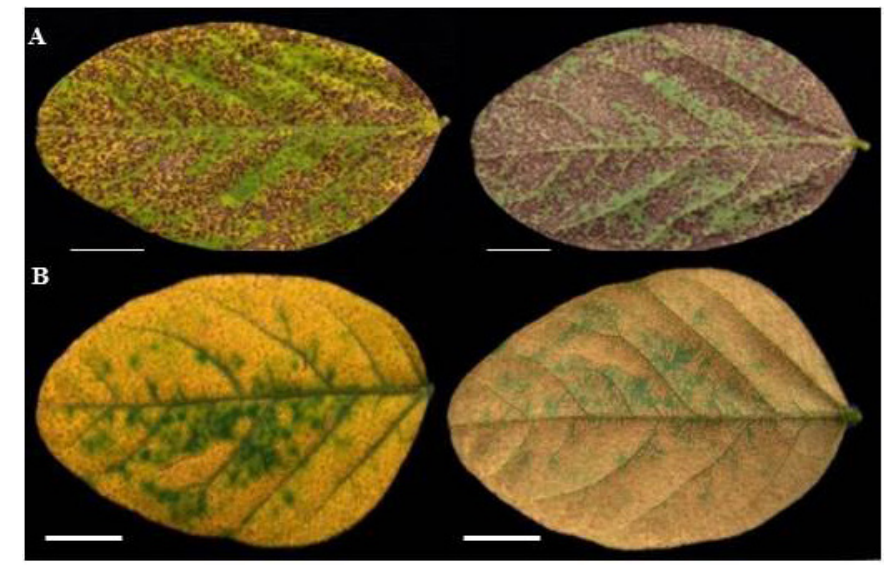

Figure 1. A. Resistance phenotype of accession PI 594 767-A characterized as "RB" lesions without sporulation 10 days after inoculation with Phakopsora pachyrhizi. B. Susceptible phenotype of cultivar 'Conquista' characterized as "TAN" lesions with significant sporulation 10 days after inoculation with P. pachyrhizi. Adaxial surface (left) and abaxial surface (right); bar, $1 \mathrm{~cm}$.

Genetics and Molecular Research 15 (3): gmr.15038475 
Table 2. Resistance segregation of Phakopsora pachyrhizi in subpopulation 26C-2, considering the segregation of a recessive gene $(3: 1)$.

\begin{tabular}{l|c|c}
\hline Phenotypic class & Number of observed plants & Number of expected plants (1:3) \\
\hline Resistant & 60 & 62.5 \\
\hline Susceptible & 190 & 187.5 \\
\hline Total & 250 & $0.133^{\mathrm{NS}}$ \\
\hline chi-square & \multicolumn{2}{|c}{71.50} \\
\hline Probability (\%) & \multicolumn{2}{|c}{} \\
\hline
\end{tabular}

NS $=$ not significant at the $5 \%$ probability level.

The subpopulation 26C-5 exhibited less sporulation and "TAN" lesions than 'Conquista' used as a control under high temperature. PI 594767-A plants exhibited a resistance reaction that was characterized by the occurrence of small necrotic lesions, and were classified as "IF" (Figure 2A).

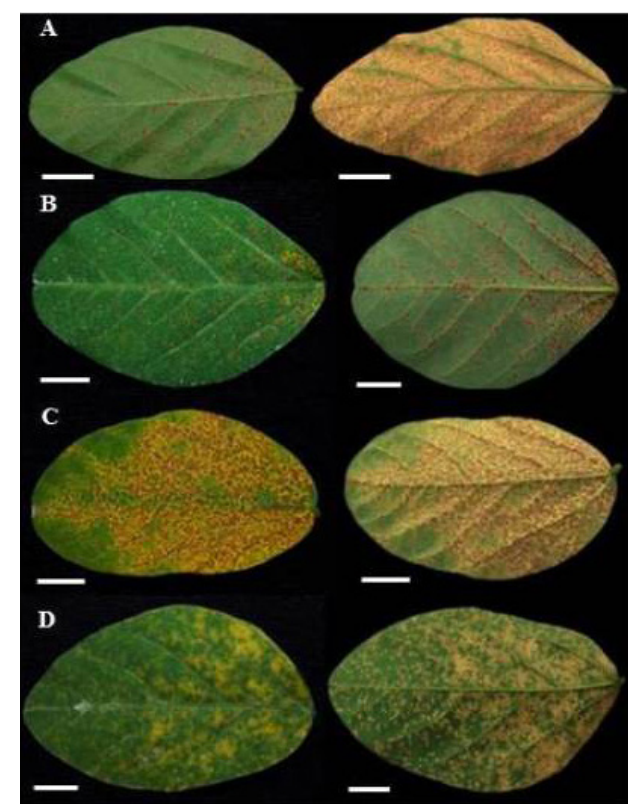

Figure 2. A. Resistance phenotype of accession PI 594767-A (left) to Phakopsora pachyrhizi characterized by the presence of small necrotic lesions (immunity with flecks, "IF"), and a susceptible phenotype of the cultivar 'Conquista' (right) with light brown lesions ("TAN" lesions) and little sporulation. In subpopulation 26C-5, different symptoms were observed in plants 10 days after inoculation with a monopustular isolate of $P$. pachyrhizi (PPUFV02). B. Resistance phenotype characterized by the presence of small necrotic lesions ("IF"). C. Resistance phenotype characterized by the presence of reddish-brown necrotic lesions with little sporulation ("RB" lesions). D. Susceptible phenotype with light brown lesions and significant sporulation ("TAN" lesions). Adaxial surface (left) and abaxial surface (right); bar, $1 \mathrm{~cm}$.

The segregating subpopulation $26 \mathrm{C}-5(\mathrm{~N}=364$ plants) contained 98 "IF" plants, 187 "RB" plants, and 79 "TAN" plants (Figure 2B, C, and D). The segregation obtained in this generation was $1: 2: 1$, indicating that resistance is controlled by a partially dominant gene (Table 3). 
Table 3. Resistance segregation of Phakopsora pachyrhizi in subpopulation 26C-5, considering the segregation of a gene with partial dominance (1:2:1).

\begin{tabular}{l|c|c}
\hline Phenotypic class & Number of observed plants & Number of expected plants (1:2:1) \\
\hline IF & 98 & 91 \\
\hline RB & 187 & 182 \\
\hline TAN & 79 & 91 \\
\hline Total & 394 & \\
\hline chi-square & & $2.26^{\mathrm{NS}}$ \\
\hline Probability (\%) & \multicolumn{2}{|c}{32.22} \\
\hline
\end{tabular}

TAN = light brown lesions; $\mathrm{RB}=$ reddish-brown lesions; $\mathrm{IF}=$ immunity with flecks; $\mathrm{NS}=$ not significant at the $5 \%$ probability level.

The different phenotypes observed also depended on the dosage of the resistance gene. Therefore, to perform a molecular analysis, 19 microsatellite loci in the parental PI 594767-A and 'Conquista' plants were assessed. Only the parental markers Satt191, Sat_191N, Sct_187r2, Sat_372, Sat_372-N, Sat_064, Sat_064N, Satt622, and Sat_275 were polymorphic. These polymorphic loci were analyzed in 10 resistant and 10 susceptible plants of the segregating subpopulation $26 \mathrm{C}-2$ separately from the two parents, in order to identify the microsatellite loci linked to resistance genes. The analysis revealed a possible link between Satt191, Sat_191N, Sct_187r2, Sat_372, Sat_372-N, Sat_064, and Sat_064N in linkage group $\mathrm{G}$ of the soybean genetic map.

An analysis of the entire 26C-2 subpopulation was conducted for Satt191, Sct_187r2, Sat_064, and Sat_372, and 26C-5 was analyzed for Satt191, Sct_187r2, and Sat_064. All of the microsatellite loci analyzed exhibited codominant segregation.

The fragment amplified by the Satt191 marker in 'Conquista' was 203 bp long, while in PI 594767-A it was 225 bp long. The marker Sat 372 amplified 300- and 292-bp fragments in 'Conquista' and PI 594767-A, respectively. The marker Sat 064 amplified a 140-bp fragment in 'Conquista' and a 115-bp fragment in PI 594767-A. Marker Sct_187r2 amplified a 304-bp region in 'Conquista' and a 288-bp region in PI 594767-A.

In subpopulation 26C-2, all of the plants with a "RB" phenotype were homozygous for the resistance gene, as demonstrated by an analysis of the linked loci Sct_187r2 and Sat_064 (Tables 4 and 5).

Table 4. Genotypes of microsatellite loci in plants of each phenotypic class observed in subpopulation 26C-2 $(\mathrm{N}=250$ plants).

\begin{tabular}{|c|c|c|c|}
\hline \multirow[t]{2}{*}{ Microsatellite locus } & \multirow[t]{2}{*}{ Genotype } & \multicolumn{2}{|c|}{ Phenotype } \\
\hline & & RB & TAN \\
\hline \multirow[t]{3}{*}{ Satt191 } & $225 / 225^{\mathrm{a}}$ & 48 & 4 \\
\hline & $225 / 203^{\mathrm{b}}$ & 11 & 112 \\
\hline & $203 / 203^{\mathrm{c}}$ & 1 & 71 \\
\hline \multirow[t]{3}{*}{ Sct_187r2 } & $288 / 288^{a}$ & 60 & 0 \\
\hline & $288 / 304^{b}$ & 0 & 130 \\
\hline & $304 / 304^{c}$ & 0 & 60 \\
\hline \multirow[t]{3}{*}{ Sat_064 } & $115 / 115^{\mathrm{a}}$ & 60 & 0 \\
\hline & $115 / 140^{\mathrm{b}}$ & 0 & 130 \\
\hline & $140 / 140^{\mathrm{c}}$ & 0 & 60 \\
\hline \multirow[t]{3}{*}{ Sat_372 } & $292 / 292^{\mathrm{a}}$ & 60 & 4 \\
\hline & $292 / 300^{\mathrm{b}}$ & 0 & 126 \\
\hline & $300 / 300^{\mathrm{c}}$ & 0 & 60 \\
\hline
\end{tabular}

aHomozygous for the allele from PI-594767-A. 'Heterozygote. 'Homozygous allele from 'Conquista'. TAN, light brown lesions; RB, reddish-brown lesions.

Genetics and Molecular Research 15 (3): gmr.15038475 
Table 5. Genetic distances (cM) between microsatellite loci and the resistance gene (R Gene) based on a segregation analysis of subpopulation $26 \mathrm{C}-2(\mathrm{~N}=250$ plants).

\begin{tabular}{l|c|c|c|c|c}
\hline Marker & Satt191 & R Gene & Sct_187r2 & Sat_064 & Sat_372 \\
\hline Satt191 & - & 7.35 & 7.25 & 8.17 & 9.02 \\
\hline R Gene & 34.52 & - & 0.00 & 0.00 & 1.60 \\
\hline Sct_187r2 & 62.00 & 59.86 & - & - & 2.00 \\
\hline Sat_064 & 58.29 & 59.86 & 101.87 & 90 & \\
\hline Sat 372 & 53.68 & 52.15 & 92.22 & 98.77 & - \\
\hline
\end{tabular}

Values above the diagonal refer to distances between the markers, and values below the diagonal refer to logarithm (base 10) of odds (LOD).

Furthermore, mapping revealed that the resistance gene was located at the same position as Sat_064 and Sct_187r2, $1.3 \mathrm{cM}$ from Sat_372 (Figure 3A). Four plants had recombination events between Sct_187r2 and Sat_064 (Table 6).

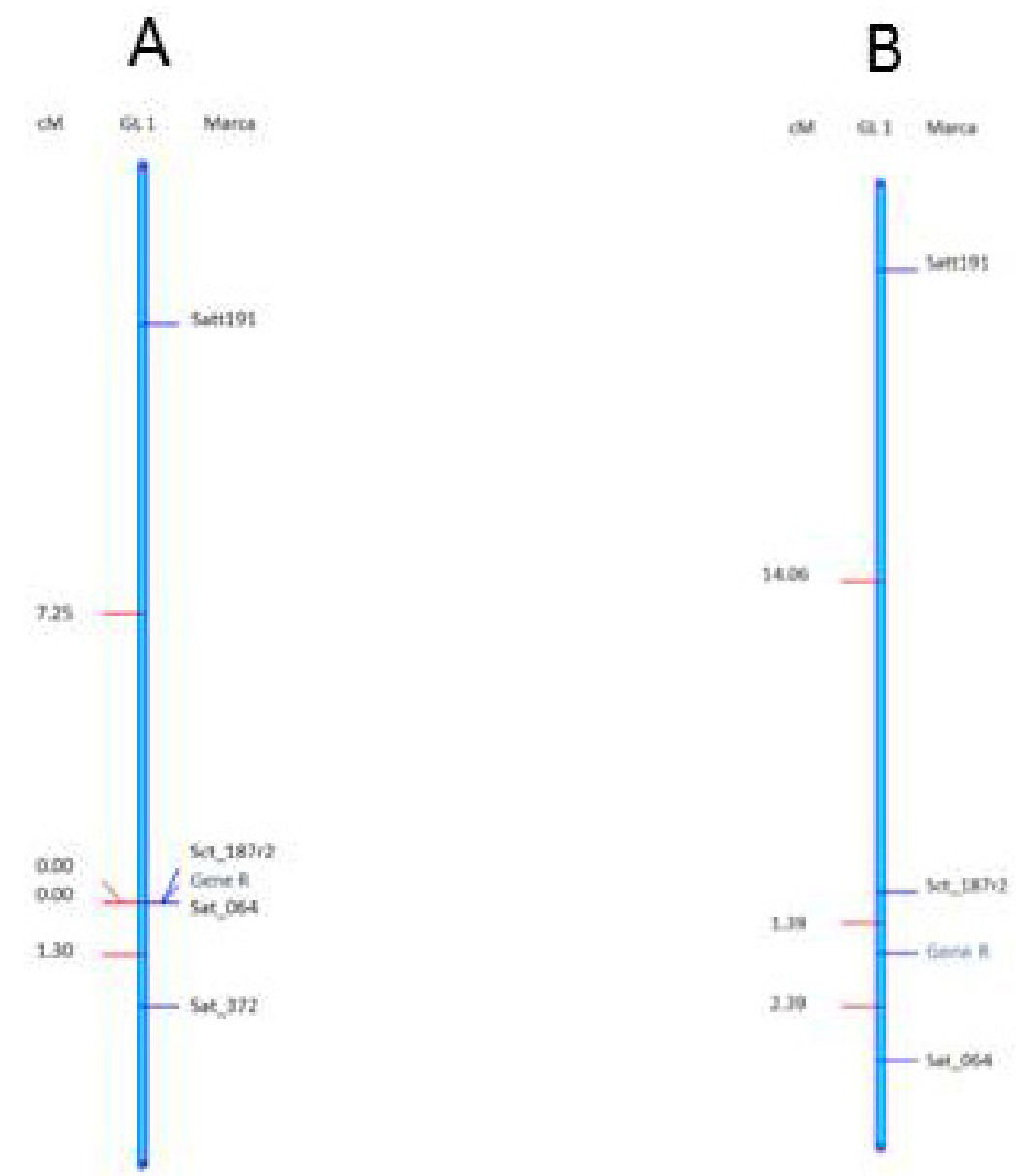

Figure 3. Linkage maps of the genomic region in PI 594767-A that contains the gene that confers resistance to Phakopsora pachyrhizi. A. Map constructed based on segregation resistance analysis and microsatellite markers of the $\mathrm{F}_{2}$ subpopulation $26 \mathrm{C}-2\left(\mathrm{~N}=250\right.$ plants). B. Map of the $\mathrm{F}_{2}$ subpopulation $26 \mathrm{C}-5(\mathrm{~N}=364$ plants) constructed using the program GQMOL 6.1. Distances (cM) were calculated using the Kosambi function.

Genetics and Molecular Research 15 (3): gmr.15038475 
Table 6. Plants in subpopulation 26C-2 with informative recombination events in the genomic region of PI 594767-A that contains the resistance gene to Phakopsora pachyrhizi.

\begin{tabular}{l|c|c|c|c|c}
\hline \multicolumn{2}{|c|}{} & \multicolumn{2}{|c|}{ Phenotype } & \multicolumn{2}{c}{ Genotype } \\
\hline & & Satt191 & Sct_1872 & Sat_064 & 3 \\
\hline $26 \mathrm{C}-2-45$ & TAN & 2 & 2 & 3 & 3 \\
\hline $26 \mathrm{C}-2-103$ & TAN & 2 & 2 & 2 & 3 \\
\hline $26 \mathrm{C}-2-130$ & TAN & 3 & 3 & 2 & 2 \\
\hline $26 \mathrm{C}-2-188$ & TAN & 3 & 3 & 2 \\
\hline
\end{tabular}

TAN, light brown lesions.

Genotypic analysis of the microsatellite loci in plants of each phenotypic class in subpopulation 26C-5 revealed an "IF" phenotype associated with a homozygous allele derived from PI 594767-A at Sct_187r2 and Sat 064, as well as a "RB" phenotype with heterozygosity and susceptibility to homozygosis for an allele derived from 'Conquista' (Table 7). Therefore, the resistance gene was in the genomic region bounded by Sct_187r2 and Sat_064, and was 1.4 and $2.4 \mathrm{cM}$ from these loci, respectively (Figure 3B). This association was not perfect only in 11 plants with recombination events between Sct_187r2 and Sat_064 (Table 8).

Table 7. Genotypes of microsatellite loci in plants of each phenotypic class in subpopulation $26 \mathrm{C}-5$ (N $=364$ plants).

\begin{tabular}{|c|c|c|c|c|}
\hline \multirow[t]{2}{*}{ Microsatellite locus } & \multirow[t]{2}{*}{ Genotype } & \multicolumn{3}{|c|}{ Phenotype } \\
\hline & & IF & RB & TAN \\
\hline \multirow[t]{3}{*}{ Satt191 } & $225 / 225^{\mathrm{a}}$ & 78 & 18 & 7 \\
\hline & $225 / 203^{b}$ & 17 & 145 & 20 \\
\hline & $203 / 203^{c}$ & 3 & 24 & 52 \\
\hline \multirow[t]{3}{*}{ Sct_187r2 } & $288 / 288^{a}$ & 97 & 5 & 0 \\
\hline & $288 / 304^{b}$ & 1 & 181 & 3 \\
\hline & $304 / 304^{c}$ & 0 & 1 & 76 \\
\hline \multirow[t]{3}{*}{ Sat_064 } & $115 / 115^{\mathrm{a}}$ & 95 & 3 & 0 \\
\hline & $115 / 140^{b}$ & 2 & 178 & 4 \\
\hline & $140 / 140^{c}$ & 1 & 6 & 75 \\
\hline
\end{tabular}

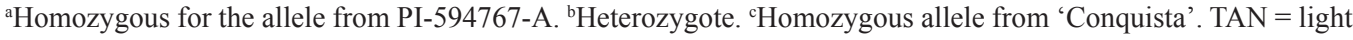
brown lesions; $\mathrm{RB}=$ reddish-brown lesions; $\mathrm{IF}=$ immunity with flecks.

Table 8. Plants with informative recombination events in the genomic region of PI 594767-A that contains the resistance gene to Phakopsora pachyrhizi.

\begin{tabular}{|c|c|c|c|c|}
\hline \multirow[t]{2}{*}{ Plant code } & \multirow[t]{2}{*}{ Phenotype } & \multicolumn{3}{|c|}{ Genotype } \\
\hline & & Satt191 & Sct_187r2 & Sat_064 \\
\hline $26 \mathrm{C}-5-2$ & RB & 2 & 2 & 3 \\
\hline $26 \mathrm{C}-5-3$ & RB & 1 & 1 & 2 \\
\hline $26 C-5-115$ & RB & 2 & 2 & 3 \\
\hline 26C-5-131 & RB & 2 & 2 & 3 \\
\hline 26C-5-145 & RB & 2 & 2 & 3 \\
\hline $26 \mathrm{C}-5-158$ & RB & 1 & 1 & 2 \\
\hline $26 C-5-179$ & RB & 2 & 2 & 3 \\
\hline 26C-5-183 & IF & 1 & 1 & 2 \\
\hline $26 C-5-324$ & RB & 1 & 1 & 2 \\
\hline $26 C-5-333$ & RB & 2 & 2 & 1 \\
\hline $26 \mathrm{C}-5-336$ & TAN & 3 & 3 & 2 \\
\hline
\end{tabular}

$\mathrm{TAN}=$ light brown lesions; $\mathrm{RB}=$ reddish-brown lesions; $\mathrm{IF}=$ immunity with flecks.

Genetics and Molecular Research 15 (3): gmr.15038475 
To investigate possible relationships between the gene identified in PI 594767-A and genes of the Rppl locus already described, the accessions PI 200492, PI 561356, PI 587880-A, PI 587886, PI 587905, PI 594538-A, PI 594754, and PI 594767-A and the cultivars 'Williams 82' and 'Conquista' were analyzed using the microsatellite loci Sct_187r2 and Sat_064, which flanked the Rpp1 locus (Table 9). This analysis identified four haplotypes. PI 561356, PI 587880-A, PI 587886, PI 587905, and PI 594538-A had the same haplotype (283/104), which was different from the haplotype (291/124) in PI 200492, source of the Rpp1 gene. Distinct haplotypes were obtained for PI 594754 (287/117) and PI 594767-A (287/115), and for the susceptible cultivars 'Conquista' and 'Williams 82' (304/140).

Table 9. Allelic variability in the microsatellite loci Sct $187 \mathrm{r} 2$ and Sat 064 in soybean accessions that contain resistance genes (R Gene) to Phakopsora pachyrhizi mapped between Sct_187r2 and Sat_064.

\begin{tabular}{l|c|c|c}
\hline \multirow{2}{*}{ Accession } & R Gene/allele of Rppl locus & \multicolumn{2}{|c}{ Microsatellite locus } \\
\cline { 3 - 4 } & & Sct_187r2 & Sat_064 \\
\cline { 3 - 4 } & & Allele (bp) & Allele (bp) \\
\hline PI 200492 & Rppl & 291 & 124 \\
\hline PI 561356 & $?$ & 283 & 104 \\
\hline PI 587880-A & Rpp1? & 283 & 104 \\
\hline PI 587886 & Rppl? & 283 & 104 \\
\hline PI 587905 & $?$ & 283 & 104 \\
\hline PI 594538-A & Rpplb & 283 & 117 \\
\hline PI 594754 & $?$ & 287 & 115 \\
\hline PI 594767-A & $?$ & 287 & 140 \\
\hline Williams 82 & - & 304 & 140 \\
\hline Conquista & - & 304 & \\
\hline
\end{tabular}

\section{DISCUSSION}

Unlike other agronomic traits, the phenotype of a plant-pathogen interaction results from the plant genotype interacting with the pathogen genotype, the influence of environmental factors on each of these genotypes, and the interaction between them. In this study, the influence of temperature on expression resistance resulted in two patterns of resistance inheritance in PI 594767-A, which were dependent on when the resistance of the segregating populations was assessed. Phenotypes in control resistant and control susceptible plants also differed between assessment periods, indicating that temperature influences fungal development and the nonexpression of the resistance gene, as observed in other plant-pathogen interactions (Zhu et al., 2010). Temperature conditions in the greenhouse (mean, $15^{\circ}-29^{\circ} \mathrm{C}$ ) fully supported the development of P. pachyrhizi, and "TAN" lesions with abundant sporulation were observed in the susceptible cultivar 'Conquista', a pattern of recessive monogenic inheritance was observed in subpopulation 26C-2, the resistance phenotype was observed in PI 594767-A plants and in plants of the segregating population characterized by the presence of "RB" lesions with no sporulation. Under higher temperatures (mean above $29^{\circ} \mathrm{C}$ ), there was less sporulation in "TAN" lesions in 'Conquista', a pattern of monogenic inheritance with partial dominance in subpopulation 26C-5, and two phenotypic resistances: "IF" in PI 594767-A plants and "RB" lesions with sporulation in subpopulation $26 \mathrm{C}-5$ plants.

"IF" and "RB" phenotypes result from different pathological events that have different temporal expressions (McLean, 1979). An immune response is the rapid prevention of colonization of infected tissue by a pathogen, the formation of few haustoria, and the formation of four to six necrotic mesophyll cells that are in contact with the pathogen, which is microscopically visible 48 to $72 \mathrm{~h}$ after inoculation. Because the resistance reaction with 
"RB" lesions is the result of a large number of necrotic cells, it allows the macroscopic visualization of necrosis and colonization stoppage about $120 \mathrm{~h}$ after inoculation. The extent of colonization, the number of necrotic cells, and the number of haustoria formed in this lesion type are intermediate between those observed in immunity and susceptibility reactions.

The necrosis observed in the immunity phenotype with necrotic flecks is probably caused by the junction of several nearby infection points due to deposition next to several uredospores during inoculation. In other words, each infection point results in the necrosis of five to six cells that is not observable macroscopically, but the joining of several events appears as a necrotic fleck and allows macroscopic visualization. Therefore, the slower development of P. pachyrhizi under high temperature conditions may have allowed plants that were carrying the resistance gene derived from PI 594767-A to create an effective resistance response against the pathogen, reflected in the different resistance phenotypes obtained. Indeed, Alves et al. (2007) observed lower ASR intensity in 'Conquista' plants inoculated and kept at temperatures around 30 and $15^{\circ} \mathrm{C}$. The different phenotypes observed also depend on the dosage of the resistance gene. In subpopulation 26C-2, all of the plants with the "RB" phenotype were homozygous for the resistance gene, as evidenced by the analysis of loci linked to Sct_187r2. The assessment of subpopulation 26C-5 showed that plants with the "RB" phenotype were heterozygous and those with the "IF" phenotype were homozygous for the resistance gene. These results show that the resistance gene is less effective in the heterozygous condition, and only provides resistance in conditions that delay pathogen development, such as high temperatures, as was the case with subpopulation $26 \mathrm{C}-5$ in this study. This condition also provided more effective containment of the pathogen in plants with a double dose (homozygous) of the resistance gene in the same population, resulting in the "IF" phenotype.

The observation of different phenotypes depending on the dosage of the resistance gene may be common for genes that confer resistance to P. pachyrhizi. Resistance alleles of the accessions PI 587905 (Alves, 2012) and PI 587886 and PI 587880A (Ray et al., 2009) also showed partial dominance gene action by exhibiting "RB" or "IF" phenotypes, depending on the gene dosage. Several studies have also shown that for the same PI accession, different resistance phenotypes ("RB" or "IF") can be obtained, depending on the isolate used in the assessments (Ray et al., 2009). It is possible that alleles that confer resistance are more sensitive to aggressive isolates of $P$. pachyrhizi, or are sensitive to variations in aggressiveness of the fungus due to environmental conditions, as observed in this study.

Regarding the optimal environmental conditions for pathogen development, the resistance of PI 594767-A to PPUFV02 is conferred by a recessive gene. The first recessive genes conferring soybean rust resistance were reported in PI 224270 and PI 200456 (Calvo et al., 2008). Later studies showed that PI 224270 has a recessive allele in Rpp2, and PI 200456 has a recessive allele in Rpp5 (Garcia et al., 2008). A recessive gene that maps the Rpp1 locus was reported recently in PI 594760B by Garcia et al. (2011). This gene shows different action modes (recessive or partially dominant), depending on the susceptible genotype (TMG06_0011 or TMG06_0012) used in crossing and heritage studies, which led Garcia et al. (2011) to suggest the presence of an allelic series at the locus of resistance, Rpp1.

The resistance gene in PI 594767-A to PPUFV02 is located in soybean linkage group G (chromosome 18) between the Sct_187 and Sat_064 markers, where Rpp1 in PI 200492 is located (Hyten et al., 2007) (Figure 3). In this region, resistance genes in PI 594538A (Rpp 1b) (Chakraborty et al., 2009), PI 587886 and PI 587880A (Rpp1?) (Ray et al., 2009), PI 561356 and PI 594760B (Garcia et al., 2011), and PI 587905 (Alves, 2012) have been mapped.

Genetics and Molecular Research 15 (3): gmr.15038475 
Therefore, there may be a series of alleles at the Rppl locus that is similar to that at locus L in flax of genes that confer resistance to Melampsora lini, the causal agent of flax rust (Ellis et al., 1999). Thirteen alleles have been reported at this locus, and each is capable of conferring resistance to a different isolate of $M$. lini.

The resistance gene in PI 594767-A may be a new allele of Rpp1, as it has a Sct_187r2-Sat_064 haplotype that is different from that in PI 200492, PI 561356, PI 587880A, $\overline{\text { PI }} 587886, \overline{\text { PI }} 587905$, PI 594538-A, and PI 594754. This feature, coupled with its ability to confer resistance against a highly virulent Brazilian isolate named BRP-2 (Yamanaka et al., 2011), makes PI 594767-A a very promising accession for resistance to soybean rust in breeding programs. The pyramiding of the resistance allele in PI 594767-A with the broadspectrum resistance genes available at loci $R p p 2, R p p 3, R p p 4, R p p 5$, and $R p p 6$ can confer more durable resistance in the field. Pyramiding in lines or in commercial varieties can be facilitated using the Sct_187 and Sat_064 markers and the microsatellite markers available and connected to the other resistance loci.

To date, most cloned resistance genes encode proteins with a nucleotide-binding site (NBS) domain and leucine-rich repeats (LRR) (Jones and Dangl, 2006). In the genome of cultivar 'Williams 82 ' that has been recently characterized (Schmutz et al., 2010), the region encompassed by the markers Sat_064 and Sct_187 is approximately $150 \mathrm{kbp}$ long and contains three analogs of NBS/LRR resistance genes. It is possible that one of these analogs in the PI 594754-A genome is a resistance gene that was mapped in this study.

The 15 individuals with informative recombination events in this region could be used for fine-scale genetic mapping of the resistance gene using new molecular markers, in order to identify homologous sequence candidates for the resistance gene and prioritizing full characterization and functional studies, as performed by Meyer et al. (2009) in the recent cloning of Rpp4. The characterization of the resistance gene of this PI, and of other genes located at the Rppl locus, provides us with a better understanding of the molecular mechanisms involved in the generation of new resistance genes at this locus, and contributes to the establishment of new strategies for the development of durable resistance to ASR.

\section{CONCLUSIONS}

Resistance of the accession PI 594767-A to a monopustular isolate of P. pachyrhizi (PPUFV02) is conferred by a recessive gene. This inheritance model was influenced by environmental conditions during the assessment: at high temperature, which is less favorable for fungal growth, a model of monogenic inheritance with partial dominance was observed. The PI 594767-A resistance gene is on chromosome 18 (GL-G), in a genomic region among the microsatellite loci Sct_187r2 and Sat_064, where the Rpp1 locus is located. The resistance gene in PI 594767-A is probably a new allele of Rpp1; therefore, it has a different haplotype at loci Sct_187r2 and Sat 064 to that in PI 200492 (the original source of Rpp1), PI 561356, PI 587880-A, PI 587886, PI 587905, PI 594538, and PI 594754-A, which also have resistance alleles that map to the Rpp1 locus.

\section{Conflicts of interest}

The authors declare no conflict of interest.

Genetics and Molecular Research 15 (3): gmr.15038475 


\section{ACKNOWLEDGMENTS}

The authors thank CNPq for financial support and Universidade Federal de Viçosa for the opportunity to use its excellent facilities.

\section{REFERENCES}

Alves DP (2012). Herança e mapeamento genético da resistência do acesso PI 587905 ao isolado monopustular PPUFV02 de Phakopsora pachyrhizi, agente causal da ferrugem asiática da soja. Master's thesis, Universidade Federal de Viçosa, Viçosa.

Alves MC, Pozza EA, Ferreira JB, Araújo DV, et al. (2007). Intensidade da ferrugem asiática (Phakopsora pachyrhizi H. Sydow \& P. Sydow) da soja [Glycine max (L.) Merr.] nas cultivares Conquista, savana e suprema sob diferentes temperaturas e períodos de molhamento foliar. Summa Phytopathol. 33: 239-244. http://dx.doi.org/10.1590/S0100$\underline{54052007000300005}$

Bromfield KR and Hartwig EE (1980). Resistance to soybean rust and mode of inheritance. Crop Sci. 20: 254-255.

Calvo ES, Kiihl RAS, Garcia A, Harada A, et al. (2008). Two major recessive soybean genes conferring soybean rust resistance. Crop Sci. 48: 1350-1354. http://dx.doi.org/10.2135/cropsci2007.10.0589

Chakraborty N, Curley J, Frederick RD, Hyten DL, et al. (2009). Mapping and confirmation of a new allele at Rppl from soybean PI 594538A conferring RB lesion-type resistance to soybean rust. Crop Sci. 49: 783-790. http://dx.doi. org/10.2135/cropsci2008.06.0335

Costa PM (2010). Caracterização e expressão transiente de genes de Phakopsora pachyrhizi que codificam proteínas secretadas. 83 f. Master's thesis, Universidade Federal de Viçosa-UFV, Viçosa.

Cruz CD and Schuster I (2006). GQMOL: aplicativo computacional para análise de dados moleculares e de suas associações com caracteres quantitativos. Versão 6.1 .

Doyle JJ and Doyle JL (1987). A rapid DNA isolation method for small quantities of fresh tissues. Phytochem. Bull. 19: 11-15.

Ellis JG, Lawrence GJ, Luck JE and Dodds PN (1999). Identification of regions in alleles of the flax rust resistance gene L that determine differences in gene-for-gene specificity. Plant Cell 11: 495-506. http://dx.doi.org/10.1105/ tpc.11.3.495

Fehr WR and Caviness JA (1977). Stages of soybean development. Iowa State University, Aimes.

Freire MCM, Oliveira LO, Almeida AMR, Schuster I, et al. (2008). Evolutionary history of Phakopsora pachyrhizi (the Asian soybean rust) in Brazil based on nucleotide sequences of the internal transcribed spacer region of the nuclear ribosomal DNA. Genet. Mol. Biol. 31: 920-931. http://dx.doi.org/10.1590/S1415-47572008005000026

Furtado GQ, Alves SAM, Czermainski ABC and Massola NS, Jr. (2008). Preservation of Phakopsora pachyrhizi uredospores. J. Phytopathol. 156: 62-64.

Garcia A, Calvo ES, de Souza Kiihl RA, Harada A, et al. (2008). Molecular mapping of soybean rust (Phakopsora pachyrhizi) resistance genes: discovery of a novel locus and alleles. Theor. Appl. Genet. 117: 545-553. http://dx.doi. org/10.1007/s00122-008-0798-Z

Garcia A, Calvo ES, Kiihl RAS and Souto ER (2011). Evidence of a susceptible allele inverting the dominance of rust resistance in soybean. Crop Sci. 51: 32-40. http://dx.doi.org/10.2135/cropsci2010.01.0037

Goellner K, Loehrer M, Langenbach C, Conrath U, et al. (2010). Phakopsora pachyrhizi, the causal agent of Asian soybean rust. Mol. Plant Pathol. 11: 169-177. http://dx.doi.org/10.1111/j.1364-3703.2009.00589.x

Hartman GL, Sinclair JB and Rupe JC (1999). Compendium of soybean diseases. 4th edn. APS Press, St. Paul, p. 128.

Hartwig EE (1986). Identification of a fourth major gene conferring resistance to rust in soybeans. Crop Sci. 26: 11351136. http://dx.doi.org/10.2135/cropsci1986.0011183X002600060010x

Hartwig EE and Bromfield KR (1983). Relationships among three genes conferring specific resistance to rust in soybeans. Crop Sci. 23: 237-239. http://dx.doi.org/10.2135/cropsci1983.0011183X002300020012x

Hyten DL, Hartman GL, Nelson RL, Frederick RD, et al. (2007). Map location of the Rpp1 locus that confers resistance to soybean rust in soybean. Crop Sci. 47: 837-838. http://dx.doi.org/10.2135/cropsci2006.07.0484

Jones JD and Dang1 JL (2006). The plant immune system. Nature 444: 323-329. http://dx.doi.org/10.1038/nature05286

Kosambi DD (1944). The estimation of map distance from recombination values. Ann. Eugen. 12: 172-175. http://dx.doi. org/10.1111/j.1469-1809.1943.tb02321.x

Li S, Smith JR, Ray JD and Frederick RD (2012). Identification of a new soybean rust resistance gene in PI 567102B. Theor. Appl. Genet. 125: 133-142. http://dx.doi.org/10.1007/s00122-012-1821-y

Genetics and Molecular Research 15 (3): gmr.15038475 
Marchetti MA, Melching JS and Bromfield KR (1976). The effects of temperature and dew period on germination and infection by uredospores of Phakopsora pachyrhizi. Phytopathology 66: 461-463. http://dx.doi.org/10.1094/ Phyto-66-461

McLean RJ (1979). Histological studies of resistance to soybean rust, Phakopsora pachyrhizi Syd. Aust. J. Agric. Res. 30: 77-84. http://dx.doi.org/10.1071/AR9790077

McLean RJ and Byth DE (1980). Inheritance of resistance to rust (Phakopsora pachyrhizi) in soybean. Aust. J. Agric. Res. 31: 951-956. http://dx.doi.org/10.1071/AR9800951

Melching JS, Dowler WM, Koogle DL and Royer MH (1989). Effect of duration, frequency, and temperature of leaf wetness periods on soybean rust. Plant Dis. 73: 117-122. http://dx.doi.org/10.1094/PD-73-0117

Meyer JDF, Silva DCG, Yang C, Pedley KF, et al. (2009). Identification and analyses of candidate genes for rpp4-mediated resistance to Asian soybean rust in soybean. Plant Physiol. 150: 295-307.http://dx.doi.org/10.1104/pp.108.134551

Michelmore RW, Paran I and Kesseli RV (1991). Identification of markers linked to disease-resistance genes by bulked segregant analysis: a rapid method to detect markers in specific genomic regions by using segregating populations. Proc. Natl. Acad. Sci. USA 88: 9828-9832.http://dx.doi.org/10.1073/pnas.88.21.9828

Oliveira ACB, Godoy CV and Martins MC (2005). Avaliação da tolerância de cultivares de soja à ferrugem asiática no Oeste da Bahia. Fitopatol. Bras. 30: 658-662. http://dx.doi.org/10.1590/S0100-41582005000600016

Ray JD, Morel W, Smith JR, Frederick RD, et al. (2009). Genetics and mapping of adult plant rust resistance in soybean PI 587886 and PI 587880A. Theor. Appl. Genet. 119: 271-280. http://dx.doi.org/10.1007/s00122-009-1036-z

Ribeiro AC, Guimarães PTG and Alvarez VVH (1999). Recomendações para uso de corretivos e fertilizantes em Minas Gerais-5a aproximação. UFV, Viçosa, p. 359.

Rodrigues B, Serafim F, Nogueira APO, Hamawaki OT, et al. (2015). Correlations between traits in soybean (Glycine max L.) naturally infected with Asian rust (Phakopsora pachyrhizi). Genet. Mol. Res. 14: 17718-17729. http://dx.doi. org/10.4238/2015.December.21.45

Schmutz J, Cannon SB, Schlueter J, Ma J, et al. (2010). Genome sequence of the palaeopolyploid soybean. Nature 463: 178-183. http://dx.doi.org/10.1038/nature08670

Souza TLPO, Dessaune SN, Moreira MA and Barros EG (2014). Soybean rust resistance sources and inheritance in the common bean (Phaseolus vulgaris L.). Genet. Mol. Res. 13: 5626-5636. http://dx.doi.org/10.4238/2014.July.25.18

Zhu Y, Qian W and Hua J (2010). Temperature modulates plant defense responses through NB-LRR proteins. PLoS Pathog. 6: e1000844.http://dx.doi.org/10.1371/journal.ppat.1000844

Yamanaka N, Yamaoka Y, Kato M, Lemos NG, et al. (2010). Development of classification criteria for resistance to soybean rust and differences in virulence among Japanese and Brazilian rust populations. Trop. Plant Pathol 35: 153-162. http://dx.doi.org/10.1590/S1982-56762010000300003

Yamanaka N, Lemos NG, Akamatsu H, Yamaoka Y, et al. (2011). Soybean breeding materials useful for resistance to soybean rust in Brazil. Jpn. Agric. Res. Q. 45: 385-395. http://dx.doi.org/10.6090/jarq.45.385

Yorinori JT and Lazzarotto JJ (2004). Situação da ferrugem asiática da soja no Brasil e na América do Sul. Documentos Embrapa 236. 30 p. ISSN 15: 16-78.

Genetics and Molecular Research 15 (3): gmr.15038475 